RASĀYAN J. Chem.

Vol. 13 | No. 1 |636 - 646| January - March | 2020 ISSN: 0974-1496 | e-ISSN: 0976-0083 | CODEN: RJCABP

\title{
LEAF EXTRACT OF Artocarpus altilis [Park.] Fosberg HAS POTENCY AS ANTIINFLAMMATORY, ANTIOXIDANT, AND IMMUNOSUPPRESSANT
}

\author{
D. H. S. Palupi ${ }^{1,3}$, D. S. Retnoningrum ${ }^{2}$, M. I. Iwo ${ }^{1}$, and A. A. Soemardji ${ }^{1}$ \\ ${ }^{1}$ Department of Pharmacology-Clinical Pharmacy, School of Pharmacy, \\ Institut Teknologi Bandung \\ ${ }^{2}$ Department of Pharmaceutics, School of Pharmacy, Institut Teknologi Bandung, Jl. Ganesha \\ 10, Bandung 40132, Indonesia \\ ${ }^{3}$ Department of Pharmacology-Clinical Pharmacy, Sekolah Tinggi Ilmu Farmasi Yayasan \\ Pharmasi, J1. Letjend. Sarwo Edi Wibowo Km 1, Semarang 50192, Indonesia \\ *E-mail: dwi.palupi@ymail.com
}

\begin{abstract}
This study aimed to evaluate the anti-inflammatory, antioxidant, and immunomodulatory of ethanolic extract of the leaf, fruit, and bark from breadfruit (Artocarpus altilis [Park.] Fosberg) which is traditionally used for the treatment of inflammation-related diseases. Ethanolic extract of these compounds at 100 and $200 \mathrm{mg} / \mathrm{kg}$ doses was orally administered in chronic inflammatory rats induced by Freund's Complete Adjuvant for 14 days to investigate their in vivo anti-inflammatory and antioxidant activity. The maximum percentage of inflammation, serum levels of peroxide radicals, and liver superoxide dismutase activity were observed, and in vitro antioxidant was measured by using the scavenging of nitric oxide and 2, 2-Diphenyl-1- picrylhydrazyl radicals methods. Also, immunomodulatory activity was evaluated in mice by the relative weight of lymphoid organs, phagocytic index, delayed-type hypersensitivity response, and haemagglutinin titer. The highest total phenolic and flavonoid content is in the leaf extract. Administration of leaf extracts Artocarpus altilis at $200 \mathrm{mg} / \mathrm{kg}$ dose showed a significant reduction in inflammation, decreased serum peroxide levels, and increased the activity of the enzyme superoxide dismutase $(\mathrm{p}<0.05)$ compared to untreated rats. All three extracts also indicated in vitro antioxidant activity, with the leaf extract, was the most significant $(\mathrm{p}<0.05)$. The immunosuppressive effect of the leaf extract in the nonspecific and specific immune system was proven significant at $200 \mathrm{mg} / \mathrm{kg}$ dose. This result indicated that $A$. altilis leaf extract significantly revealed anti-inflammatory, antioxidant, and immunosuppressant activities at $200 \mathrm{mg} / \mathrm{kg}$.

Keywords: Artocarpus altilis, Complete Freund's Adjuvant, Anti-inflammatory, Antioxidants, Immunosuppressant, Traditional Medicines
\end{abstract}

(C) RASĀYAN. All rights reserved

\section{INTRODUCTION}

The immune system gets inflamed when microbial infections, tissue injuries, and other dangerous conditions occur. This response is the body's standard mechanism for maintaining survival. Inflammation is a usual mechanism of the immune system to ensure survival in response to microbial infections, tissue injuries, and other dangerous conditions. ${ }^{1}$ The inflammatory process includes several events, such as widened venules and arterioles, increased vascular permeability, and leukocyte infiltration into the tissues. Some primary regulators involved in the gene expression of proinflammatory molecules act as mediators in said inflammatory process. ${ }^{2}$ Uncontrolled acute inflammation will cause considerable tissue damage and will initiate several chronic inflammatory-related diseases, such as metabolic syndrome and autoimmunity. ${ }^{3}$

The right treatment for immune-mediated inflammatory disorders aims to form initial control of inflammation and prevent tissue damage with minimal side effects. At present, the available antiinflammatory drugs do not meet these requirements, often causing an unacceptable degree of side effects, Rasayan J. Chem., 13(1), 636-646(2020)

http://dx.doi.org/10.31788/RJC.2020.1315519

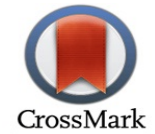


RASĀYAN J. Chem.

Vol. 13 | No. 1 |636 - 646| January - March | 2020

or exhibiting less therapeutic effects than desired, or both. Plant-based products are some of the alternative treatments which can be considered to control chronic inflammation and inflammatory-related diseases.

Chronic inflammation induced by complete adjuvant Freund (CFA) is an animal inflammation model that has been used widely used due to its high sensitivity and prolonged swelling time. ${ }^{4} \mathrm{CFA}$ is an adjuvant that has a sterile paraffin oil composition containing inactive Mycobacterium tuberculosis. CFA induces inflammation symptoms associated with mast cell activation, leukocyte infiltration, and secretion of free radicals and cytokines in the circulation. ${ }^{5}$ Inflammation in this experimental model can measure the activity of inflammation mediators, the property of anti-inflammatory or analgesic, and the efficacy of the particular compound. ${ }^{6}$

Breadfruit [Artocarpus altilis (Park.) Fosberg], famously known as Sukun in Indonesia, is one of the tropical plants of the Moraceae family. This plant grows in many tropical and subtropical regions. Moraceae generally contains bioactive compounds such as flavonoids, stilbene, and lectins ${ }^{7}$. Apart from being a food source, A. altilis is also widely used in traditional medicine. People living in the tropical region of Asia, especially Indonesia, use the fruit porridge as a tonic for the liver and use the leaf stew to treat liver cirrhosis, hypertension, and diabetes. ${ }^{8}$

A relevant review revealed that several compounds in A. altilis were successfully isolated, and their biological activities were proven. Most compound isolates are from prenylated flavonoid classes, including artonin A, artonin B, dihydrocycloartomunin, heteroflavanones, cylomorucine, cycloartomunin, artocarpanone A, and cudraflavone E. Biological activities including antiatherogenic, antihypertensive, and antiatherosclerotic. ${ }^{7,9,10,11}$

Studies of $A$. altilis anti-inflammatory properties have been carried out through in vivo and in vitro testing. Isolates from A.altilis fruit, 5,7,40-trihydroxy-6-geranyl flavanone have been shown to bring down the activity of inflammatory mediators in human monocytes induced by S100B. ${ }^{12}$ A. altilis methanol extract leaf was found to inhibit skin inflammation and inflammation associated with epithelial carcinogenesis in mice. ${ }^{13}$ Some geranyl flavonoid compounds isolated from A. altilis leaf showed in vitro anti-inflammatory activity in RAW 264 cells by suppressing the induction of iNOS and COX-2 protein expression. ${ }^{14}$ Studies on carrageenan-induced inflammatory murine exhibited in vivo anti-inflammatory properties of ethyl acetate extract of $A$. altilis leaf with higher selectivity in cyclooxygenase 2 (COX2). ${ }^{15}$ However, there is no evidence of in vivo activity against chronic inflammatory conditions.

This study aims to provides evidence of in vivo anti-inflammatory activity ethanol extracts from some of the leaf, bark, and fruit of $A$. altilis, as well as their ability to reduce free radicals. Anti-inflammatory and antioxidant evaluations of these extracts observed in experimental models of chronic inflammation. The potential of $A$. altilis extracts as an immunomodulatory also evaluated against the specific and nonspecific immune system. Extracts with these three properties are expected to be worthy candidates as an active ingredient for the treatment of immune-mediated inflammatory-related diseases.

\section{EXPERIMENTAL}

\section{Material}

Artocarpus altilis leaf, bark, and fruit were collected from Dago region, Bandung, West Java, Indonesia. In this study, only the yellow-colored leaf that was still attached to the plant during sampling time was chosen. The unripe $A$. altilis fruit was also collected, and the stem bark used was the outermost skin of the tree trunk. Leaves, whole fruit, and bark were cleaned from soil and dirt, dried at room temperature (25$28^{\circ} \mathrm{C}$ ), and mashed using a dry blender. Plant specimens were identified at Herbarium Bandungense, School of Life Science and Technology, Bandung Institute of Technology, Indonesia.

Animals

Female Wistar rats and Swiss mice aged 2-3 months selected for these studies. The animals were maintained at the Animal Laboratory, School of Pharmacy, Institut Teknologi Bandung, under standard environmental conditions ( 12 hours light-dark cycle a $25 \pm 2^{\circ} \mathrm{C}$, and $50 \pm 15 \%$ relative humidity). All methods of animal experiments were performed through the approval of the Ethics Committee for Experimental Use, Institut Teknologi Bandung, and documented with code 01-02 / KEPHP-ITB / 11 2017. 


\section{RASĀYAN J. Chem.}

Vol. 13 | No. 1 |636 - 646| January - March | 2020

\section{Chemicals}

Complete Freund's adjuvant was obtained from Sigma-Aldrich Corp., all chemical reagents for phytochemical screening (ammonia, toluene, chloroform, hydrochloric acid, Dragendorff reagent, Mayer reagent, Steasny reagent), saline phosphate buffer, and Sheep Red Blood Cells (SRBC) were obtained from Biofarma, superoxide dismutase (SOD) and peroxide antioxidant kits were purchased from BioAssay system, quercetin, and methylprednisolone that were obtained from Dexa Medika. All chemicals used were of pharmaceutical standards.

\section{Preparation of Extracts}

The fine powder of leaf, bark, and fruit of A. altilis was macerated repeatedly with $96 \%$ ethanol in 5 consecutive days with solvent replacement every 24 hours. The Maserati was filtered through Whatman filter paper and evaporated in a vacuum using a rotary evaporator to thick extract. This thick extract was weighed to determine the percentage of extraction yield based on the dry weight. All extracts were stored at $4{ }^{\circ} \mathrm{C}$ until further use.

\section{Phytochemical Screening}

Initial phytochemical screening of $A$. altilis leaf extract (AALE), $A$. altilis bark extract (AABE), and $A$. altilis fruit extract (AAFE) was performed for detecting alkaloids, saponins, phenolics, flavonoids, and tannins.

\section{Total Component of Phenolic}

The mixture of sample and Folin-Ciocalteu reagent (1:10) were added with $4 \mathrm{ml}$ of 15\% Na2CO3 solution after incubation for 5 minutes, followed by the addition of $1 \mathrm{ml}$ of deionized distilled water. The solution was mixed thoroughly with vortex and was let for 1 hour in the dark to react. The absorbance of the solution was measured at $745 \mathrm{~nm}$. The total phenolic component was calculated using extrapolation of gallic acid calibration curves in various concentrations and expressed as the equivalent of milligrams of gallic acid (GAE) per gram of dry sample. ${ }^{16}$

\section{Total Flavonoids}

The mixture of $0.5 \mathrm{ml}$ sample extract and $2 \mathrm{ml}$ distilled water was added $0.15 \mathrm{ml}$ sodium nitrite $(5 \%$ $\left.\mathrm{NaNO}_{2}, \mathrm{~b} / \mathrm{v}\right)$, incubated for 6 minutes. After adding $0.15 \mathrm{ml}$ of aluminum trichloride $\left(10 \% \mathrm{AlCl}_{3}\right)$ and left for 6 minutes, followed by adding $2 \mathrm{ml}$ of sodium hydroxide $(\mathrm{NaOH}, 4 \% \mathrm{w} / \mathrm{v})$ and distilled water to $5 \mathrm{ml}$. Incubation of the mixture for 15 minutes, then measured using a spectrophotometer at $510 \mathrm{~nm}$. Total flavonoids content was expressed as milligrams of quercetin equivalent (Q) per gram extract.

\section{Evaluation of Antioxidant In vitro Activity}

\section{DPPH radical scavenging assay}

Three $\mathrm{mL}$ sample solution with different concentrations added by $0.1 \mathrm{mM}$ DPPH in an ethanol solution, incubated at room temperature for 30 minutes. The measurement of sample absorbance was carried out at $517 \mathrm{~nm} .{ }^{17}$ The inhibition percentage of DPPH radical was calculated with the following equation:

$$
\text { DPPH scavenging }(\%)=((\text { A control }- \text { A sample })) /(\text { A control }) \times 100
$$

Where, $\mathrm{A}_{\text {control }}$ as the absorbance of the solution without the extract, and $\mathrm{A}_{\text {sample }}$ as the absorbance of the solution with the extract in different concentrations.

\section{Nitric Oxide Radical Scavenging Assay}

Extracts sample in various concentrations were added to $10 \mathrm{mM}$ sodium nitroprusside in $0.025 \mathrm{M}$ phosphate buffer solution until an ending volume of $3 \mathrm{ml}$, and let the mixture reacts for $150 \mathrm{~min}$ at room temperature. The experimental control, mixture without the sample (replaced by the same amount of buffer), was prepared in the same manner as for testing. The mixture of $0.5 \mathrm{~mL}$ was added to Griess reagent ( $1 \%$ sulphanilamide, $2 \%$ phosphoric acid, and $0.1 \%$ naphthyl ethylene diamine dihydrochloride), 
RASĀYAN J. Chem.

Vol. 13 | No. 1 |636 - 646| January - March | 2020

incubated for 30 minutes $\left(25^{\circ} \mathrm{C}\right)$, and was measured the absorbance at $546 \mathrm{~nm}^{18}$. The test was done in triplicate, using quercetin as a comparative compound. Percentage inhibition of Nitric Oxide radicals was calculated from the ratio of the sample's absorbance $\left(\mathrm{A}_{\text {sample }}\right)$ to the control's absorbance $\left(\mathrm{A}_{\text {control }}\right)$ following the equation:

$$
\text { NO Scavenging }(\%)=((\text { A control }- \text { A sample })) /(\text { A control }) \times 100
$$

\section{CFA-induced Inflammation}

The anti-inflammatory and antioxidant activity of A. altilis extract was determined in chronic inflammatory rats induced by CFA. Inflammation assessment was done during the chronic phase (after the first 24 hours). Inflammation was caused by subcutaneous injection of $0.1 \mathrm{ml} \mathrm{CFA}$ in the left hind paw. Induction was carried out in all groups except the normal (healthy) group.

\section{Evaluation of Anti-inflammatory Activity}

The rats were grouped into nine with five in each group in the following set: Normal Group: Healthy animal treated with vehicle solution only

Control Group: Chronic inflammation untreated, received vehicle solution only

MP group: Chronic inflammation received methylprednisolone $(40 \mathrm{mg} / \mathrm{kg})$ as drug standard

AALE 100 Group: Chronic inflammation received AALE $100 \mathrm{mg} / \mathrm{kg}$ dose

AALE 200 Group: Chronic inflammation received AALE $200 \mathrm{mg} / \mathrm{kg}$ dose

AAFE 100 Group: Chronic inflammation received AAFE $100 \mathrm{mg} / \mathrm{kg}$ dose

AAFE 200 Group: Chronic inflammation received AAFE $200 \mathrm{mg} / \mathrm{kg}$ dose

AABE 100 Group : Chronic inflammation received AABE $100 \mathrm{mg} / \mathrm{kg}$ dose

AABE 200 Group : Chronic inflammation received AABE $200 \mathrm{mg} / \mathrm{kg}$ dose

Rats were treated by $A$. altilis extract once a day for 14 consecutive days after the CFA injection. Measurement of edema was carried out before and after the CFA injection (days 1, 4, 7, and 10) using a plethysmometer. Each foot measurement was done twice, and the average foot volume was calculated. All rats were given ad libitum water and food during the experiment. The blood sample was collected at the end of the test. Animals were sacrificed, and their livers were isolated for the measurement of antioxidant activity.

\section{Evaluation of Antioxidant Activity}

The separated blood serum can be stored at $-40^{\circ} \mathrm{C}$ until it was used to estimate the radical peroxide colorimetrically using a commercial kit (BioAssay System). The method utilizes the orange chromogenic reaction of $\mathrm{Fe}^{3+}$-xylenol, which will form a purple complex when $\mathrm{Fe}^{2+}$ oxidized by the peroxide present in the sample. The measurement of color intensity was carried out at a wavelength of 540-610 nm.

The isolated liver organs were weighed and homogenized in cold phosphate buffer $(0.05 \mathrm{M} \mathrm{pH} 7.4)$ 1:20 $\mathrm{w} / \mathrm{v}$. The measured sample was a supernatant from the liver homogenate centrifugation $(10,000 \mathrm{rpm})$ for 15 minutes at $4{ }^{\circ} \mathrm{C}$. Evaluation of SOD activity was determined by the photoreduction nitroblue tetrazolium (NBT) method. A $200 \mu \mathrm{L}$ solution containing $0.8 \quad \mathrm{mM} \quad \mathrm{N}, \quad \mathrm{N}, \quad \mathrm{N}$, N'tetramethylethylenediamine (TEMED) in $16 \mathrm{mM}$ phosphate buffer ( $\mathrm{pH}$ 7.4), six $\mu \mathrm{M}$ riboflavin and $85 \mu \mathrm{M}$ nitroblue tetrazolium (NBT) were added to each well on a 96-wells microplate. Forty $\mu \mathrm{L}$ Samples and standards (in various concentrations) are added to the well as planned. The mixture was exposed to neon light for 15 minutes and measured absorption at $560 \mathrm{~nm} .{ }^{19}$ The activity of SOD expressed as units per milligram of protein.

\section{Evaluation of Immunomodulatory Activity}

An immunomodulatory activity assay was performed on Swiss female mice. The control group was given a normal saline solution, and the treatment group was given an extract of A. altilis $(100$ and $200 \mathrm{mg} / \mathrm{kg})$ for seven consecutive days. The standard drug group was administered methylprednisolone at $40 \mathrm{mg} / \mathrm{kg}$ dose. Animal termination was performed on the last day of observation (day 8), and the relative weight of organs (liver, spleen, and thymus) was calculated per $100 \mathrm{~g}$ body weight. 
RASĀYAN J. Chem.

Vol. 13 | No. 1 |636 - 646| January - March | 2020

\section{Effect of Extract on Phagocytic Activity}

The phagocytic activity observed by the test of carbon clearance. On the $7^{\text {th }}$ day of treatment, mice were injected intravenously with $0.1 \mathrm{ml} / 10 \mathrm{~g}$ of Indian ink (temperature $37^{\circ} \mathrm{C}$ ) through the tail vein, and the blood was collected at 3 and 12 minutes after the injection with a retro-orbital puncture. A $20 \mu \mathrm{L}$ blood sample was added in $2 \mathrm{ml}$ of $1 \%$ acetic acid solution, and then the absorbance was measured at $675 \mathrm{~nm}$. After the animal was sacrificed, the lymphoid organs (thymus, spleen, and liver) were separated and scaled to determine the relative weight of the organ. Phagocytic index calculation $(\alpha)$ was done using the following formula:

$$
\begin{aligned}
& k=(\log \text { OD } 1-\log \mathrm{OD} 2) /(\mathrm{t} 2-\mathrm{t} 1) \\
& \alpha=\sqrt[3]{\mathrm{k}} \times \text { Bodyweight } /(\text { Liver Weight }+ \text { Spleen Weight })
\end{aligned}
$$

Where, OD1 is the absorbance at 3 minutes; OD2 is the absorbance at 12 minutes; T1 is blood collection time at 3 minutes; $\mathrm{T} 2$ is the time of blood collection at 12 minutes.

\section{Effect of Extracts on Humoral Immunity Parameters}

Mice that had been grouped and receiving treatment for seven days were immunized with $1 \%$ SRBC as much as $0.1 \mathrm{ml} / 10 \mathrm{~g}$ intravenously (expressed as day 0 ). After day 5, blood samples were collected for serum preparation. A twofold serial dilution of serum samples was made with $25 \mu \mathrm{L}$ PBS (pH 7.2) in 96well microtiter and added in each well $25 \mu \mathrm{L} \mathrm{1 \%} \mathrm{SRBC} \mathrm{in} \mathrm{the} \mathrm{normal} \mathrm{saline.} \mathrm{For} 1$ hour, the plates were incubated at $37^{\circ} \mathrm{C}$. Hemagglutination was observed using a light microscope. Antibody titers were shown at the highest dilution that had the most significant agglutination.

\section{Effect of Extracts on Cell-mediated Immunity Parameters}

The impact of $A$. altilis extract on cell-mediated immune responses was studied through the DelayedType of Hypersensitivity (DTH) against SRBC. ${ }^{20}$ Mice were immunized with $1 \%$ SRBC $0.1 \mathrm{~mL} / 10 \mathrm{~g}$ intraperitoneally, and that event was expressed as day 0. Five days after the immunization, the thickness of the animal's feet was measured, and the animal was then challenged by injecting $50 \mu 1$ SRBC in the right hind paw. Foot thickness was measured 24 hours after the challenge, and DTH was calculated as a percentage compared to the foot measurement before immunization.

\section{Statistical Analysis}

The total flavonoid and phenolic contents were calculated as equivalence with quercetin and gallic acid. Pearson correlation test was used to evaluate the correlation between total phenolic or flavonoid content and antioxidant activity. Data were statistically evaluated in SPSS software using a one-way analysis of variance (ANOVA), followed by LSD test. The values of $\mathrm{P}<0.05$ were stated as statistically significant.

\section{RESULTS AND DISCUSSION}

Qualitative phytochemical studies of $A$. altilis extracts exhibited the presence of flavonoids, steroids/triterpenoids, and saponins. The highest yield of A.altilis extract was fruit extract (13.87\%), followed by leaf extract (8.28\%) and bark extract (4.62\%). Most of the bioactive compounds in A. altilis originated from the phenylpropanoid pathway, and they are phenolics and flavonoids. ${ }^{21}$ These components are known to provide bioactive activity in medicinal plants.

Evaluation of anti-inflammatory and antioxidant in vivo activity from A. altilis in this study was carried out in an integrated manner with chronic inflammatory animal models. The induction of CFA causes local inflammation in the injection site, which is indicated by an increase in the volume of rat feet. After the treatment of $A$. altilis plant extracts for seven consecutive days, AALE $200 \mathrm{mg} / \mathrm{kg}$ exhibited significant inhibition of foot swelling compared to the control group (Fig.-1). Previous research proved that $A$. altilis leaf extract was able to reduce acute inflammation in carrageenan-induced mice. ${ }^{15}$

Chronic inflammation produces high oxygen absorption, due to the infiltration of immune cells such as leukocytes and mast cells, which is followed by the formation of reactive oxygen species (ROS) and their 
RASĀYAN J. Chem.

Vol. 13 | No. 1 |636 - 646| January - March | 2020

release in the affected area. The production of these reactive species is increasing sharply due to the occurrence of inflammatory mediator secretions, such as cytokines, chemokines, and arachidonic acid. ${ }^{2}$ In this study, chronic inflammation after CFA injection caused oxidative stress, which was shown in the control group to be a significant increase in serum peroxide levels $(p<0.05)$ compared to the normal group. On the contrary, the endogenous antioxidant activity of the control group decreased significantly $(\mathrm{p}<0.05)$ compared to the healthy group. Peroxide radicals are formed from superoxide $(\mathrm{O} 2)$, both spontaneously and with the help of dismutase enzymes. Peroxide is a slightly reactive compound, but the reduction of peroxide will produce hydroxyl radical (HO), which is a robust oxidizer that can cause tissue damage and initiate lipid peroxidation to form peroxyl radicals and other cytotoxic molecules. ${ }^{22}$ The administration of plant extracts reduced peroxide levels ( $p<0.05$ ), and AALE at $200 \mathrm{mg} / \mathrm{kg}$ dose showed the lowest peroxide level while increasing SOD activity. (Fig.-2A and 2B)

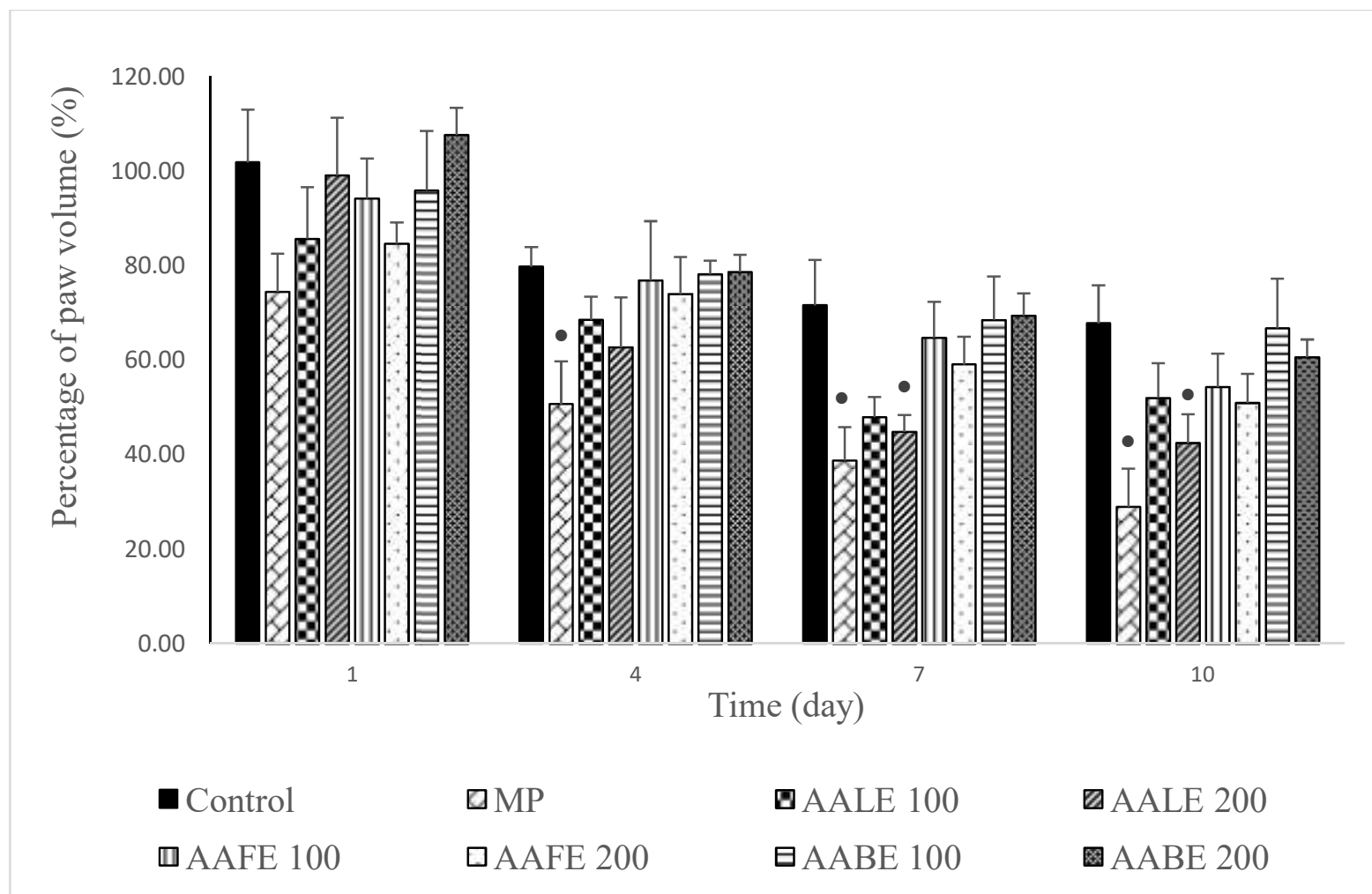

Fig.-1: Time Course Effects of Extracts from A. altilis (100 and $200 \mathrm{mg} / \mathrm{kg}$ ) or Methylprednisolone $(40 \mathrm{mg} / \mathrm{kg}) \mathrm{on}$ CFA-induced Rats in Increased Paw Volume. Values represented as Mean \pm SEM $(n=5) . \bullet p<0.05$ to Compare between Control Group.

The antioxidant in vitro assay results showed that the three extracts of A.altilis had the potential to scavenge DPPH and NO radicals. AALE proved to be more effective in lowering NO formation than others, although the strength was not higher than quercetin as a standard. The extract concentration required to inhibit radical activity 50\%, IC50, as shown in Table-1. Referring to the classification of antioxidant capacity by Blois (1958), AALE and AAFE can be classified as strong antioxidants, whereas $\mathrm{AABE}$ is a moderate antioxidant. ${ }^{23}$

Phenolic and flavonoid compounds are bioactive compounds found in many plants and have the potential to reduce free radicals. ${ }^{24}$ In vivo and in vitro test results indicated that AALE has the highest antioxidant potential. Phytochemical analysis of extracts showed that they contained flavonoids, and the most significant total phenolic and flavonoids content found in AALE (Table-2). The significance of AALE in free radical scavenging was probably related to the total content of flavonoid and phenolic. This result 
RASĀYAN J. Chem.

Vol. 13 | No. 1 |636 - 646| January - March | 2020

follows several reports which state that $A$. altilis leaf contains more phenolic and prenylated flavonoids than the fruit and bark parts. ${ }^{8,23-24}$

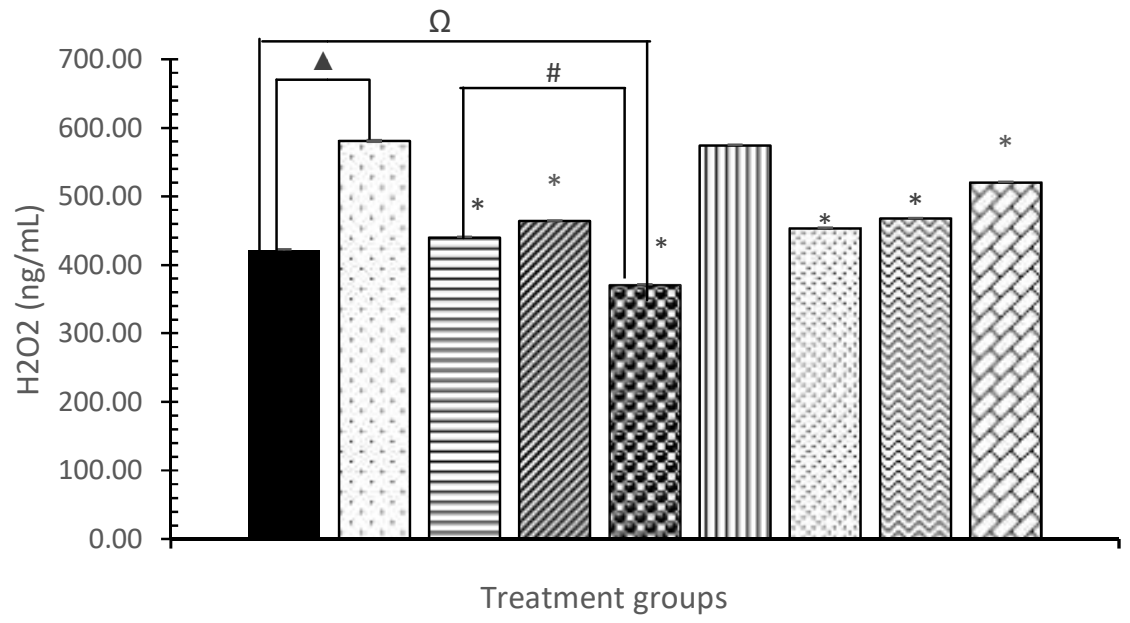
- Normal
$\square$ Control
日MP
ㄱALE 100
AALE 200
口AAFE 100
๑AFE 200
因ABE 100
$\triangle \mathrm{AABE} 200$

\#

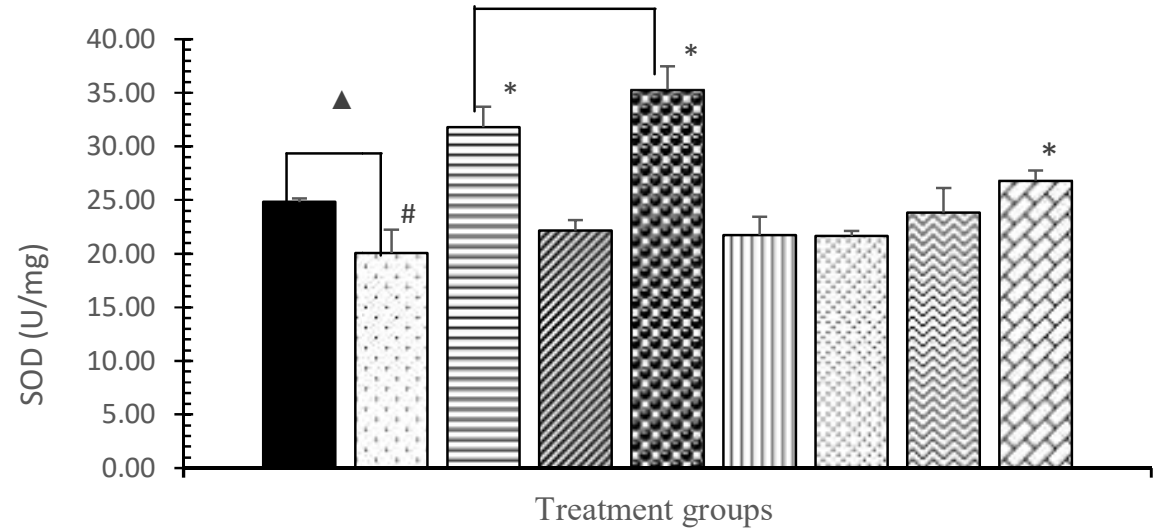

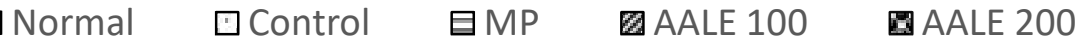

Fig.-2: Antioxidant Ex Vivo Activity of Artocarpus altilis Extracts. (A) Variation of Serum Levels of Peroxide and (B) Variation of Liver Homogenate Levels of SOD due to Treatment with A. altilis Extracts during the Chronic Phase of CFA-induced Inflammation. All Values represented as the mean $\pm \operatorname{SEM}(n=5) . \Delta p<0.05$ was used to compare between Control and Normal Groups; * $\mathrm{p}<0.05$ was used to distinguish between Control and Treated Groups; $\Omega \mathrm{p}<0.05$ was used to compare between Normal and AALE $200 \mathrm{mg} / \mathrm{kg}$ Treated Group, $\# \mathrm{p}<0.05$ was used to compare between Methylprednisolone compared to AALE $200 \mathrm{mg} / \mathrm{kg}$ Treated Group.

Table-1: Antioxidant Activity of Artocarpus altilis Extract by a Different Method

\begin{tabular}{l|c|c}
\hline \multirow{2}{*}{ Extract } & \multicolumn{2}{|c}{$\mathrm{IC}_{50}(\mathrm{mg} / \mathrm{mL})$} \\
\cline { 2 - 3 } & $\mathrm{DPPH}$ & $\mathrm{NO}$ \\
\hline AALE & $0.072 \pm 0.00$ & $0.454 \pm 0.11$ \\
\hline AABE & $0.145 \pm 0.01$ & $3.788 \pm 0.22$ \\
\hline AAFE & $0.066 \pm 0.00$ & $7.123 \pm 0.65$ \\
\hline Quercetin & & $0.03 \pm 0.01$ \\
\hline
\end{tabular}

Values are means \pm SEM 
RASĀYAN J. Chem.

Vol. 13 | No. 1 |636 - 646| January - March | 2020

Table-2: Total Phenolic and Total Flavonoids Content of A. altilis

\begin{tabular}{c|c|c}
\hline \multirow{2}{*}{ altilis Extract } & $\begin{array}{c}\text { Phenolic Total Content } \\
\text { (mg GAE/100 mg extract) }\end{array}$ & $\begin{array}{c}\text { Flavonoid Total Content } \\
\text { (mg QE/ 100 mg extract) }\end{array}$ \\
\hline Leaf Extract & $13.05 \pm 0.05$ & $12.25 \pm 0.26$ \\
\hline Bark Extract & $7.44 \pm 0.04$ & $4.07 \pm 0.12$ \\
\hline Fruit Extract & $12.93 \pm 0.05$ & $7.36 \pm 0.3$ \\
\hline \multicolumn{2}{c}{ Values are means \pm SEM }
\end{tabular}

However, there are exciting things about the correlation between scavenging activity and total phenolic and flavonoids. The relationship was determined using Person analysis, and the results proved that the scavenging activity was strongly related to total phenolic $(\mathrm{r}=0.9929)$ but did not correlate with total flavonoids $(r=0.583)$. These results mean that the compounds of A. altilis leaf, which may play a role in scavenging free radicals, were phenolic non-flavonoids. Non-flavonoid phenolic compounds known to exist in A.altilis are Moracin M and oxyresveratrol.

Inflammatory events, always involving innate and acquired immunity, if not handled properly and become chronic, will produce several disorders, such as autoimmune. ${ }^{27}$ Macrophages as professional antigen-presenting cells are components of the innate immune system that play a role in the process of phagocytosis. The study results showed that $A$. altilis extract affected phagocytic activity in macrophage function, presented in Fig.-3. Treatment with AALE (200 mg / kg BW) and AABE (100 mg / kg BW) for seven days was shown to significantly reduce phagocytic activity $(\mathrm{p}<0.05)$.

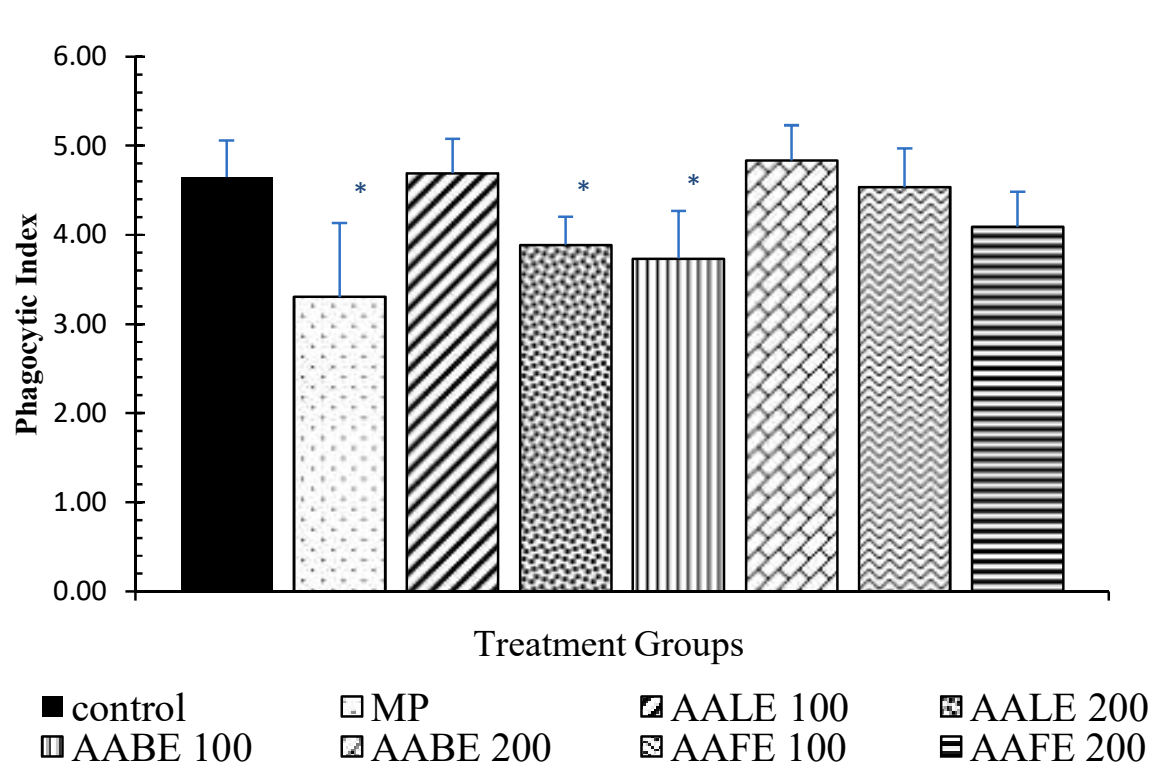

Fig.-3: The Effect of Artocarpus altilis on Non-specific Immunity as Assessed by The Phagocytic Index. Values represented as mean $\pm \mathrm{SEM} ; * \mathrm{p}<0.05$ when compared with the Control Group

Suppression activity also appeared on humoral and cellular immunity. In the measurement of hemagglutination titers (Table-3), the group with the administration of AALE at $200 \mathrm{mg} / \mathrm{kg}$ dose exhibited the same titer value as methylprednisolone treated group, and the value was below the control group titers. AAFE at $200 \mathrm{mg} / \mathrm{kg}$ dose also showed a slight decrease in the antibody titer value. While the other treatment groups showed the same or above the titer value of the control group, suppression of macrophages and the subset of B lymphocytes activities involved in antibody synthesis can cause decreased production of antibodies against SRBC due to the administration of the extract. ${ }^{28}$

DTH responses correlate directly with cell-mediated immunity (CMI). The reduction in DTH response demonstrates the effect of suppression of lymphocytes and accessory cells needed for the expression of 
RASĀYAN J. Chem.

Vol. 13 | No. 1 |636 - 646| January - March | 2020

this reaction by plant active compounds. The reduced sensitivity of $T$ lymphocytes causes a decrease in the conversion to lymphoblasts and the production of various molecules, including proinflammatory cytokines. ${ }^{29}$ This condition causes fewer scavenger cells, which lead to the reaction site when animals challenged by antigens, a condition characterized by a decrease in foot edema. The study exhibited that there was a significant reduction in the thickness of the foot of animals treated with AALE and AAFE at 100 and $200 \mathrm{mg} / \mathrm{kg}$ doses, respectively (Table-3). The prenylated flavonoid was thought to be one of the bioactive compounds of plants responsible for immunosuppressive activity. ${ }^{30}$

Table-3: Effect of Artocarpus altilis Extracts on Antibody Titer by Using SRBC as The Antigen and on DTH Response in Mice

\begin{tabular}{l|c|c}
\hline \multicolumn{1}{c|}{ Treatment Groups } & Titre Level & $\begin{array}{c}\text { DTH Response } \\
\text { (\% increase in paw volume) }\end{array}$ \\
\hline Control & $1: 512$ & $31,81 \pm 6.27$ \\
\hline Methylprednisolone & $1: 192$ & $10,90 \pm 0.59^{*}$ \\
\hline AALE 100 & $1: 768$ & $10,56 \pm 0.32^{*}$ \\
\hline AALE 200 & $1: 192$ & $9,13 \pm 0.34^{*}$ \\
\hline AAFE 100 & $1: 1536$ & $10,56 \pm 0.32^{*}$ \\
\hline AAFE 200 & $1: 256$ & $11,18 \pm 0.51^{*}$ \\
\hline AABE 100 & $1: 1536$ & $25,90 \pm 6.94$ \\
\hline AABE 200 & $1: 512$ & $28,95 \pm 4.15$ \\
\hline Values are means \pm SEM $(n=5)$ &
\end{tabular}

$* p<0.05$ Comparison between normal control and extract-treated groups

Nowadays, glucocorticoids (such as methylprednisolone) are still the drugs of choice for chronic inflammation-related diseases, especially rheumatoid arthritis. Glucocorticoid anti-inflammatory activity is generally associated with its ability to inhibit vasodilation and increase vascular permeability that occurs after inflammation, thereby reducing the emigration of leukocytes to inflamed sites. ${ }^{31}$ However, the use of high-dose and long-term glucocorticoids cause serious side effects, including adrenal suppression, Cushing's Syndrome, immune suppression, and several metabolic syndromes. ${ }^{32}$ The administration of AALE at $200 \mathrm{mg} / \mathrm{kg}$ dose showed an antiinflammatory activity comparable to methylprednisolone $(40 \mathrm{mg} / \mathrm{kg})$ with a relatively smaller immunosuppressant effect.

The prenyl group in A. altilis flavonoids increases the lipophilicity of the compound, which allows it to bind more firmly to the cell membrane and results in a higher biological activity compared to the original flavonoids. ${ }^{33}$ Different results have been obtained in studies on prenylated resveratrol, which found a free radical scavenging activity almost two-fold lower than resveratrol. ${ }^{34} \mathrm{~A}$. altilis leaf extract has the potential to be used as complementary therapy of inflammatory-related diseases (such as autoimmune), due to the insignificant side effects on body weight and suppression effect on the immune system compared to methylprednisolone. Further studies related to the use of AALE at $200 \mathrm{mg} / \mathrm{kg}$ dose on autoimmune animal models are currently in progress.

\section{CONCLUSION}

This preliminary study demonstrates the anti-inflammatory, antioxidant, and immunosuppressive activities in Artocarpus altilis. The leaf extract of $A$. altilis was shown to provide higher effectiveness in these activities compared to bark and fruit extracts. Therefore, the extract of A.altilis leaf is very potential to be used as a complementary drug in the treatment of diseases associated with inflammation.

\section{ACKNOWLEDGMENT}

The author would like to thanks the Ministry of Research, Technology, and Higher Education of the Republic of Indonesia for financially supporting this research. The name of the grant is Beasiswa Unggulan Dosen Indonesia batch PK 1-2016, and the grant number is 20161141041007.

\section{REFERENCES}

1. A.U. Ahmed, Frontiers in Biology, 6(4), 274(2011), DOI:10.1007/s11515-011-1123-9.

2. P. Arulselvan, M.T. Fard, W.S. Tan, S. Gothai, S. Fakurazi, M.E. Norhaizan, and S.S. Kumar, 
Oxidative Medicine and Cellular Longevity, 2016, 1(2016), DOI:10.1155/2016/5276130.

3. M. Perretti, M.M. Teixeira, M.A. Sugimoto, and L.P. Sousa, Frontiers in Immunology, 7(160), 1(2016), DOI:10.3389/fimmu.2016.00160.

4. J.C. Fehrenbache, M.R. Vasko, and D.B. Duarte, Current Protocols in Pharmacology, 510(7503), 84(2015), DOI:10.1002/0471141755.ph0504s56.

5. Y. Li and R. Kakkar, J. Wang, Frontiers in Pharmacology, 9(December), 1(2018), DOI: 10.3389/fphar.2018.01341.

6. K.E. Mccarson, Current Protocols in Pharmacology, 70(September), 1(2015), DOI: 10.1002/0471141755.ph0504s70.

7. M.S. Sikarwar, B.J. Hui, K. Subramaniam, B.D. Valeisamy, L.K. Yean, and K. Balaji, Journal of Applied Pharmaceutical Science, 4(8), 91(2014), DOI:10.7324/JAPS.2014.40818.

8. U.B. Jagtap and V.A. Bapat, Journal of Ethnopharmacology, 129, 142(2010), DOI: 10.1016/j.jep.2010.03.031.

9. O.A. Adaramoye and O.O. Akanni, Advances in Pharmacological Sciences, 2014, 1(2014), DOI: $10.1155 / 2014 / 605425$.

10. J.M. Siddesha, N. Angaswamy, and B.S. Vishwanath, Natural Product Research, 25(20), 1931(2011), DOI: 10.1080/14786419.2010.497962.

11. Y. Wang, T. Deng, L. Lin, Y. Pan, and X. Zheng, Phytotherapy Research, 22(9), 1052(2006), DOI: $10.1002 /$ ptr. 1990.

12. J.A. Lin, S.C. Fang, C.H. Wu, S.M. Huang, and G.C. Yen, Journal of Agricultural and Food Chemistry, 59(1), 105(2011), DOI:10.1021/jf103455g.

13. J. Lin, H. Chen, and G. Yen, Molecular Nutrition \& Food Research, 58, 206(2014), DOI:10.1002/mnfr.201300248.

14. C.L. Hsu, F.R. Chang, P.Y. Tseng, Y.F. Chen, M. El-Shazly, Y.C. Du and S.C. Fang, Planta Medica, 78, 995(2012), DOI:10.1055/s-0031-1298580.

15. N. Fakhrudin, S. Hastuti, A. Andriani, S. Widyarini, and A. Nurrochmad, International Journal of Pharmacognosy and Phytochemical Research, 7(6), 1080(2015).

16. I. Bajalan, M. Zand, M. Goodarzi, and M. Darabi, Asian Pacific Journal of Tropical Biomedicine, 7(2), 144(2017), DOI:10.1016/j.apjtb.2016.11.022.

17. Ş. Bahçeci, N. Yıldırım, Ö. Gürsoy-Kol, S. Manap, M. Beytur, and H. Yüksek, Rasayan Journal of Chemistry., 9 (3), 494(2016)

18. S.S. Volluri, S.R. Bammidi, S.C. Chippada, and M. Vangalapati, Rasayan Journal of Chemistry, 4(2), 381(2011)

19. Y. Deawati, D. Onggo, I. Mulyani, I. Hastiawan, and D. Kurnia, Molekul, 12(1), 61(2017), DOI: 10.20884/1.jm.2017.12.1.294.

20. S. Raj and K.M. Gothandam, Food and Chemical Toxicology, 81, 151(2015), DOI: $10.1016 /$ j.fct.2015.04.026.

21. M.S. Sikarwar, B.J. Hui, K. Subramaniam, B.D. Valeisamy, L.K. Yean, and K. Balaji, Journal of Applied Pharmaceutical Science, 5(05), 94(2015), DOI:10.7324/JAPS.2015.50518.

22. S. Nimse and D. Pal, Royal Society of Chemistry Advances, 5, 27986(2015), DOI: $10.1039 / C 4 R A 13315 C$

23. M.S. Blois, Nature, 181, 1199(1958).

24. D. Tungmunnithum, A. Thongboonyou, A. Pholboon, and A. Yangsabai, Medicines, 5(93), 1(2018), DOI: 10.3390/medicines5030093.

25. S.S. Shamaun, M. Rahmani, N.M. Hashim, H. B. M., Ismail, M. A. Sukari, G. E. C. Lian, and R. Go, Journal of Natural Medicines, 64(4), 478(2010), DOI:10.1007/s11418-010-0427-4.

26. Y. Wang, K. Xu, L. Lin, Y. Pan, and X. Zheng, Phytochemistry, 68(9), 1300(2007), DOI:10.1016/j.phytochem.2007.01.009.

27. C. Dinarello, Cell., 140(6), 935(2013), DOI:10.1016/j.cell.2010.02.043.

28. K. Nazimek, W. Ptak, J. Marcinkiewicz, and K. Bryniarski, Journal of Physical Therapy and Health Promotion, 1, 36(2013), DOI:10.18005/PTHP0101005.

29. S.A. Condotta and M.J. Richer, PLoS Pathogen, 13(10), 1(2017), 
RASĀYAN J. Chem.

Vol. 13 | No. 1 |636 - 646| January - March | 2020

DOI:10.1371/journal.ppat.1006618.

30. X.Yang, J. Yang, and J. He, Trends Food Science Technology, xx, 1(2015), DOI: $10.1016 /$ j.tifs.2015.03.007.

31. A.C. Liberman, M.L. Budziñski, C.Sokn, R.P. Gobbini, and E. Arzt, Frontiers in Endocrinology, 9(5), 1(2018), DOI:10.3389/fendo.2018.00235.

32. S.A. Irmak and B. Alan, 2018, Side Effects of Glucocorticoids, in Pharmacokinetics and Adverse Effects of Drugs - Mechanisms and Risks Factors. London, United Kingdom: IntechOpen, pp. 92124, DOI: 10.5772/intechopen.72019.

33. X. Chen, E. Mukwaya, M-S. Wong, Y. Zhang, Pharmaceutical Biology, 52(5), 655(2014), DOI: $10.3109 / 13880209.2013 .853809$.

34. T.M. Siregar, E. Budianto, H. Cahyana, W. Wibowo, Rasayan Journal of Chemistry, 11(4), 17651770 (2018), DOI:10.31788/RJC.2018.1143051

[RJC-5519/2019] 